\title{
Reclassification of Two Strains of Arthrobacter oxydans and Proposal of Arthrobacter nicotinovorans sp. nov.
}

\author{
YUKIKO KODAMA, ${ }^{*}$ HIROSHI YAMAMOTO, NORIHIDE AMANO, AND TERUO AMACHI \\ Institute for Fundamental Research, Suntory Ltd., Wakayamadai, \\ Shimamoto-cho, Mishima-gun, Osaka 618, Japan
}

\begin{abstract}
Arthrobacter oxydans DSM 419 and DSM 420 have chemical and microbiological properties that are consistent with assignment to the genus Arthrobacter. Both organisms have the lysine-alanine-threonine-alanine peptidoglycan type. DNA-DNA pairing studies indicated that $A$. oxydans DSM 419 should be reclassified as Arthrobacter ureafaciens and that $A$. oxydans DSM $420^{\mathrm{T}}$ forms the nucleus of a distinct genomic species. We propose that $A$. oxydans DSM 420 should be reclassified as Arthrobacter nicotinovorans sp. nov. The type strain is strain DSM 420.
\end{abstract}

Arthrobacter strains are classified into seven groups according to peptidoglycan type (7). Arthrobacter oxydans and Arthrobacter polychromogenes strains have a lysine-serinethreonine-alanine type of peptidoglycan. Despite the importance of peptidoglycan composition in Arthrobacter systematics, $A$. oxydans DSM 419 and DSM 420 were classified mainly on the basis of their ability to oxidize nicotine $(2,5)$.

The results of subsequent comparative taxonomic studies indicated that $A$. oxydans DSM 419 and DSM 420 differ from the type strain of $A$. oxydans, strain DSM 20119. By using a new analytic method, the presence of particular dipeptides can be detected in cell wall peptidoglycan hydrolysates by comparing the retention times of peaks with the retention times of synthesized dipeptides.

In this study, we found that $A$. oxydans DSM 419 should be reclassified as Arthrobacter ureafaciens and that $A$. oxydans DSM 420 forms the nucleus of a new species, Arthrobacter nicotinovorans.

\section{MATERIALS AND METHODS}

Bacterial strains. Culture collection abbreviations are as follows: ATCC, American Type Culture Collection, Rockville, Md.; DSM, Deutsche Sammlung von Mikroorganismen und Zellkulturen $\mathrm{GmbH}$, Braunschweig, Germany; JCM, Japan Collection of Microorganisms, Riken, Saitama, Japan; IAM, Institute of Applied Microbiology, University of Tokyo, Tokyo, Japan; SAM, Culture Collection of the Institute for Fundamental Research, Suntory Limited, Osaka, Japan.

We used the following test strains: Arthrobacter aurescens SAM $0298^{\mathrm{T}}$ (= IAM $\left.12340^{\mathrm{T}}\right)$, Arthrobacter citreus SAM $0302^{\mathrm{T}}$ (= IAM $12341^{\mathrm{T}}$ ), Arthrobacter histidinolovorans SAM $0296^{\mathrm{T}}\left(=\mathrm{JCM} 2520^{\mathrm{T}}\right)$, Arthrobacter ilicis $\mathrm{SAM} 1581^{\mathrm{T}}$ $\left(=\right.$ ATCC $\left.14264^{\mathrm{T}}\right), A$. oxydans SAM 1562 (= DSM 419), $A$. oxydans SAM 0173 (= JCM $3873=\mathrm{DSM} 419), A$. oxydans SAM 1563 (= DSM 420), $A$. oxydans SAM 0174 (= JCM $3874=\mathrm{DSM} 420), A$. oxydans $\mathrm{SAM} 0156^{\mathrm{T}}\left(=\mathrm{JCM} 2521^{\mathrm{T}}=\right.$ DSM $\left.20119^{\mathrm{T}}\right), A$. oxydans SAM $1560^{\mathrm{T}}\left(=\mathrm{DSM} 20119^{\mathrm{T}}\right), A$. polychromogenes $\mathrm{SAM} 0161^{\mathrm{T}}\left(=\mathrm{JCM} 2523^{\mathrm{T}}\right)$, and $A$. ureafaciens $\mathrm{SAM} 0299^{\mathrm{T}}$ (= IAM $1658^{\mathrm{T}}$ ) ( $\mathrm{T}=$ type strain).

Cell morphology. Cell shape and pleomorphism were de-

\footnotetext{
* Corresponding author.
}

termined by using cells grown in shake tubes containing Trypticase soy broth (catalog no. 11768; BBL Microbiology Systems, Cockeysville, Md.) at $30^{\circ} \mathrm{C}$. The Gram reaction was determined by using cells grown on Trypticase soy broth supplemented with $1.8 \%$ agar at $30^{\circ} \mathrm{C}$ for $24 \mathrm{~h}$. Motility was examined by using the hanging drop method and cells grown on $\mathbf{L}$ broth (1\% Polypeptone [Daigo Eiyou], $0.5 \%$ yeast extract [Difco], $0.5 \% \mathrm{NaCl}, 0.1 \%$ glucose; $\mathrm{pH} 7.0$ ) supplemented with $1.8 \%$ agar at $30^{\circ} \mathrm{C}$ for $24 \mathrm{~h}$. Flagellar distribution was observed by using negatively stained $(1 \%$ [wt/vol] phosphotungstic acid in distilled water, $\mathrm{pH} 7.0$ ) preparations that were viewed with a transmission electron microscope (model JEM 1200 EX; JEOL Ltd., Tokyo, Japan).

Physiological and biochemical characteristics. Nitrate reduction and starch hydrolysis were tested in nutrient broth supplemented with $0.1 \% \mathrm{KNO}_{3}$ and $0.1 \%$ soluble starch, respectively. Tolerance to sodium chloride was tested in Trypticase soy broth supplemented with $10 \% \mathrm{NaCl}$; utilization of organic compounds as sole carbon sources was tested by using the method of Seiler et al. (11); assimilation of organic acids was tested by using the method of Yamada and Komagata (19); and vitamin requirements were tested by using the methods of Owens and Keddie (9). Urea formation from creatinine and urea formation from uric acid were examined by using the method of Krebs and Eggleston (8), and production of nicotine blue was tested by using the method described by Sguros (12). All of these tests were done at $30^{\circ} \mathrm{C}$ for 1 week.

Preparation of cell wall peptidoglycan. The test strains were grown in $\mathbf{L}$ broth. Bacterial cells were harvested by centrifugation in the logarithmic phase of growth, washed with $0.1 \mathrm{M}$ phosphate buffer ( $\mathrm{pH} 7.2)$, and then disrupted in a sonic oscillator (Branson model 250 Sonifier) for 10 to 30 $\min$ at $5^{\circ} \mathrm{C}$. Unbroken cells were removed by centrifugation at 3,000 to $5,000 \times g$ for 10 to $15 \mathrm{~min}$. The supernatant solution was supplemented with $4 \%$ sodium dodecyl sulfate and heated at $100^{\circ} \mathrm{C}$ for $40 \mathrm{~min}$. After cooling, it was centrifuged at $10,000 \times g$ for $30 \mathrm{~min}$, and the precipitate was washed with warm water by centrifugation at room temperature, suspended in 5\% trichloroacetic acid, and heated at $90^{\circ} \mathrm{C}$ for $20 \mathrm{~min}$. The precipitate was collected and washed three times with water by centrifugation, and then it was freeze-dried.

Quantitative determination of amino acid composition. The amino acid composition of cell walls was determined by 
(a)

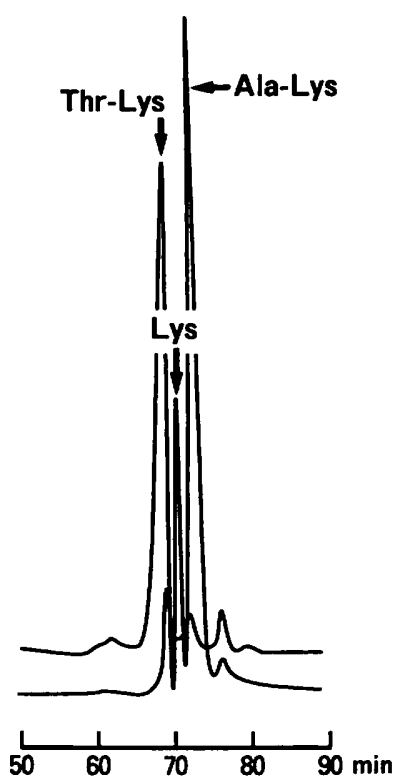

(b)

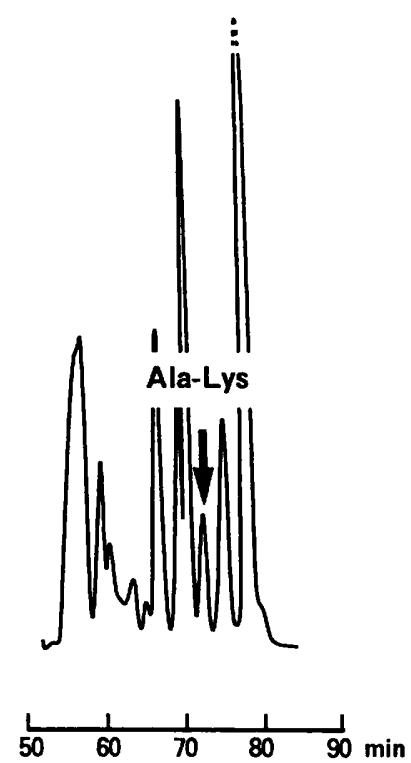

(c)

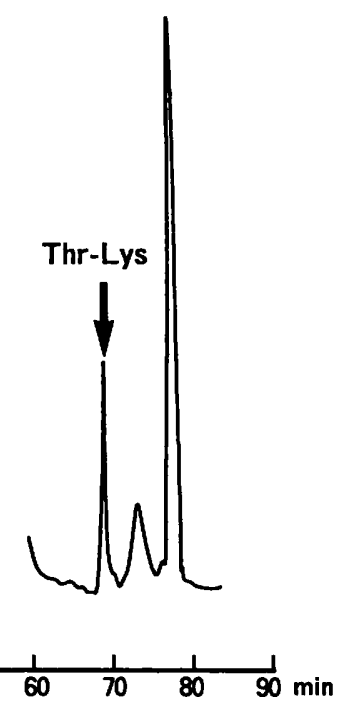

FIG. 1. Chromatograms of synthesized dipeptides and partial hydrolysates of peptidoglycans, as determined by using an automatic amino acid analyzer. (a) Lysine and the synthesized dipeptides Thr- $\varepsilon$-Lys and Ala- - -Lys. (b) Partial acid hydrolysate of the Lys-Ala-Thr-Ala peptidoglycan prepared from $A$. aurescens SAM $0298^{\mathrm{T}}$. (c) Partial acid hydrolysate of the Lys-Thr-Ala 2 peptidoglycan prepared from $A$. citreus SAM $0302^{\mathrm{t}}$.

using the method of Komagata and Suzuki (7). Approximately $1 \mathrm{mg}$ of cell walls was hydrolyzed for $16 \mathrm{~h}$ at $100^{\circ} \mathrm{C}$ in $1 \mathrm{ml}$ of $6 \mathrm{~N} \mathrm{HCl}$ in a tube that was tightly closed with a Teflon-lined screw cap. The hydrolysate was filtered and washed with water. The filtrate was dried and dissolved in $0.02 \mathrm{~N} \mathrm{HCl}$. The amino acid composition was determined by using a model 835-50 amino acid analyzer (Hitachi Ltd., Tokyo, Japan). The following abbreviations are used below for the amino acids: Ala, alanine; Lys, lysine; Ser, serine; Thr, threonine; Glu, glutamic acid.

Determination of peptidoglycan structure. A partial acid hydrolysate of the cell wall preparations was prepared by hydrolyzing approximately $1 \mathrm{mg}$ of cell walls in $1 \mathrm{ml}$ of $4 \mathrm{~N}$ $\mathrm{HCl}$ for 30 to $60 \mathrm{~min}$ at $100^{\circ} \mathrm{C}$. The presence of a particular dipeptide in partial acid hydrolysates of cell walls was determined by comparing the peaks with the peaks of synthesized dipeptides, using the amino acid analyzer.

Synthesis of dipeptides. Two dipeptides, Ala- $\varepsilon$-Lys and Thr- $\varepsilon$-Lys, were synthesized with Z-Thr(Z-Ala) and Z-Lys$\mathrm{OMe} \cdot \mathrm{HCl}$ by using the method of Bodanszky et al. (1).

Determination of cellular fatty acid composition. Cellular fatty acid composition was determined by using the method described by Suzuki and Komagata (15). Cells were cultivated in shake flasks containing $F$ medium (1\% Bacto Peptone [Difco], $0.5 \%$ yeast extract [Difco], $0.5 \%$ Casamino Acids [Difco], $0.5 \%$ malt extract [Nacalai tesque], $0.05 \%$ $\mathrm{KH}_{2} \mathrm{PO}_{4} ; \mathrm{pH} 7.2$ ) at $30^{\circ} \mathrm{C}$ for $24 \mathrm{~h}$. Cellular fatty acids were extracted by methanolysis with benzene-methanol-sulfuric acid (10:20:1, vol/vol), and the methyl esters were analyzed by using a model 663-30 gas-liquid chromatograph (Hitachi Ltd.) equipped with a $10 \%$ diethyleneglycol succinate column (length, $5 \mathrm{~m}$ ) and a flame ionization detector at $180^{\circ} \mathrm{C}$.

Determination of isoprenoid quinones. Isoprenoid quinones were extracted from freeze-dried cells with chloroformmethanol $(2: 1, \mathrm{vol} / \mathrm{vol})$ and purified by thin-layer chromatog- (a)

(b)
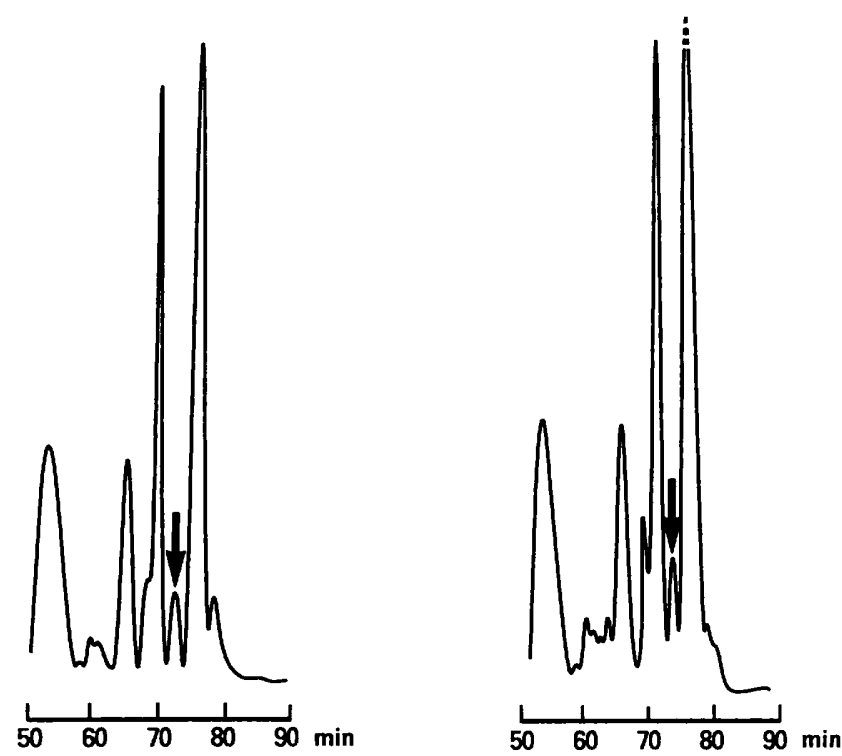

FIG. 2. Chromatograms of partial acid hydrolysates of peptidoglycans, as determined by using an automatic amino-acid analyzer. (a) Partial acid hydrolysate of peptidoglycan prepared from strain SAM 1562. (b) Partial acid hydrolysate of peptidoglycan prepared from strain SAM 1563. The arrows indicate the peaks of the Ala- $\varepsilon$-Lys dipeptide. 
raphy. The purified menaquinones were determined by using reverse-phase high-performance liquid chromatography (17). The abbreviations used below for menaquinones are in the form MK- $n\left(\mathrm{H}_{m}\right)$, with $n$ indicating the number of isoprene units in the side chain and $m$ indicating the number of hydrogen atoms saturating the isoprenoid chain.

Isolation of DNA. DNA was isolated by using the method of Tamaoka et al. (16) and cells that were cultivated for $24 \mathrm{~h}$ at $30^{\circ} \mathrm{C}$ in shake flasks containing $\mathrm{L}$ broth supplemented with $0.5 \%$ glycine.

Determination of DNA base composition. DNA base composition was determined by reverse-phase high-performance liquid chromatography after enzymatic hydrolysis of the DNA (18).

DNA-DNA hybridization. DNA-DNA hybridization was performed at $45^{\circ} \mathrm{C}$ in microdilution wells (3). DNA was labeled with photobiotin (Photoprobe Biotin; Vector Laboratories).

\section{RESULTS}

Morphological characteristics. $A$. oxydans SAM 1562 and SAM 1563 were pleomorphic; most cells in 2-day-old cultures were coccoid. The coccoid cells became irregularly rod shaped after $6 \mathrm{~h}$ when they were transferred to fresh medium; many cells were arranged at angles to each other to give $\mathrm{V}$-shaped forms. As growth proceeded, the rod-shaped cells became shorter and were eventually replaced by coccoid cells. The rods were motile by means of a few lateral flagella. Both organisms were gram positive in young cultures but subsequently became gram variable. The organisms were asporogenous, not acid fast, and obligately aerobic.

Physiological and biochemical characteristics. The results of the physiological and biochemical tests are shown in Table 1. A. oxydans SAM 1562 differed from the type strain of $A$. oxydans, strain SAM 0156, in lacking nitrate reduction, starch hydrolysis, growth in the presence $10 \% \mathrm{NaCl}$, and motility. $A$. oxydans SAM 1563 could be distinguished from the type strain of $A$. oxydans, strain SAM 0156 , by its lack of nitrate reduction and motility.

Quantitative determination of amino acid compositions of cell wall peptidoglycans. The Lys-Ala-Thr-Glu molar ratio of the cell wall peptidoglycans of $A$. oxydans SAM 1562 and SAM 1563 was $1: 4: 1: 1$, which placed these organisms in either the wall type Lys-Thr-Ala 2 group or the wall type Lys-Ala-Thr-Ala group (4). However, in $A$. oxydans type strain SAM 0156, which was in the wall type Lys-Ser-ThrAla group, the Lys-Ala-Thr-Ser-Glu ratio was 1:3:1:1:1.

Determination of peptidoglycan structure. The chromatograms of the partially hydrolyzed peptidoglycans obtained by using the automatic amino acid analyzer are shown in Fig. 1 and 2. An Ala- $\varepsilon$-Lys peak was found in the partial hydrolysate of the Lys-Ala-Thr-Ala peptidoglycan type. In contrast, a Thr- $\varepsilon$-Lys peak was found in the partial hydrolysate of the Lys-Thr-Ala 2 peptidoglycan type. The partially hydrolyzed peptidoglycans of $A$. oxydans SAM 1562 and SAM 1563 (Fig. 2) showed that these organisms belong to the peptidoglycan type Lys-Ala-Thr-Ala group.

Fatty acid, menaquinone, and DNA base compositions. The cellular fatty acids, the predominant menaquinones, and the DNA base compositions of $A$. oxydans SAM 1562 and SAM 1563 and related organisms are shown in Table 2. The major cellular fatty acid components were 12-methyltetradecanoic acid (anteiso $\mathrm{C}_{15}$ ) and 14-methylhexadecanoic acid (anteiso $\mathrm{C}_{17}$ ); the contents of normal acids varied among the test

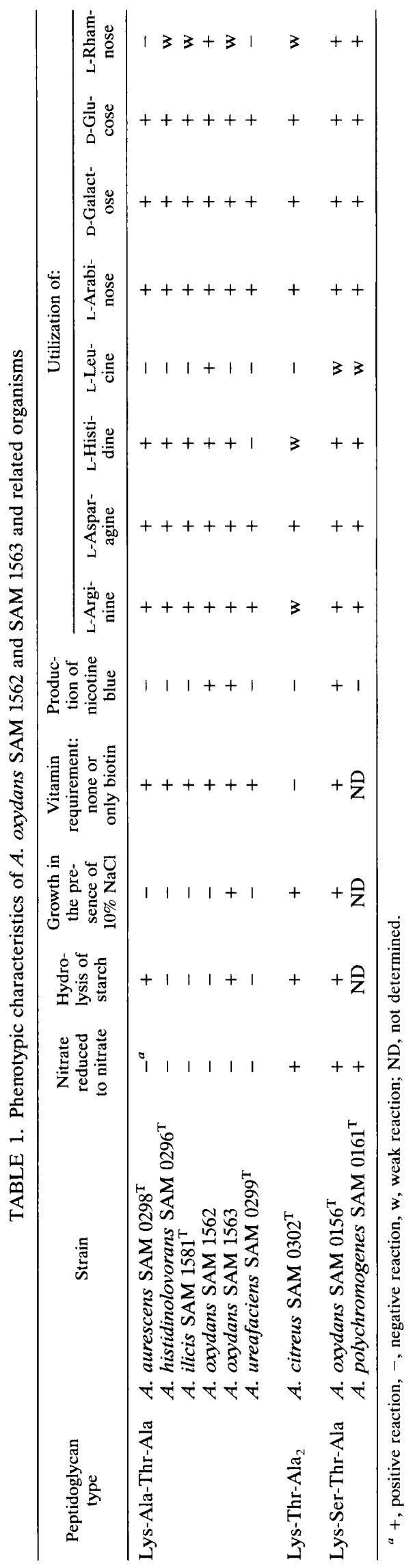




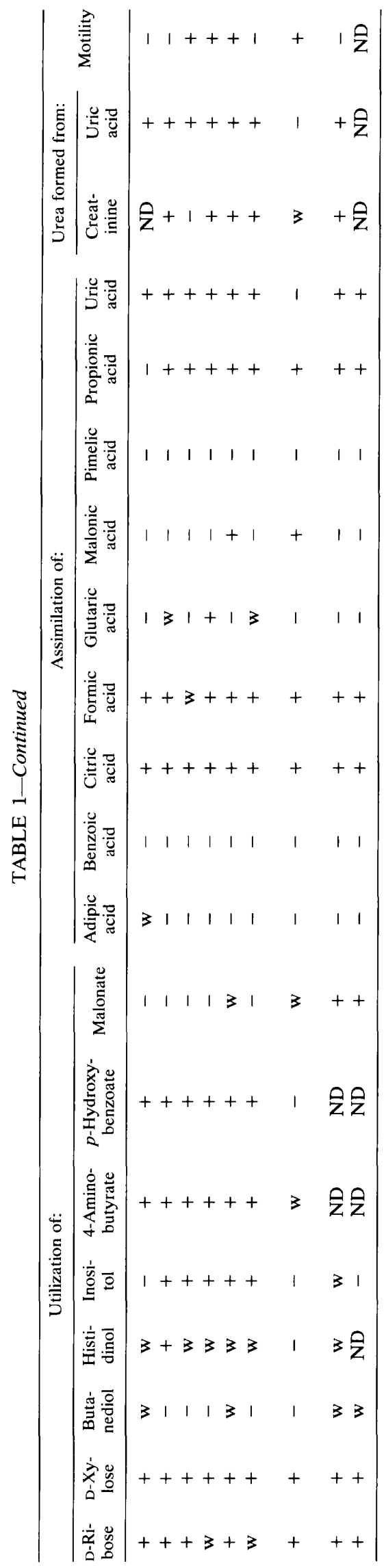

strains. $N$-hexadecanoic acid (normal $\mathrm{C}_{16}$ ) was found in the species with the Lys-Thr-Ala 2 peptidoglycan type and the Lys-Ser-Thr-Ala peptidoglycan type, where it accounted for approximately $10 \%$ of the total fatty acids detected. However, in the species with the Lys-Ala-Thr-Ala peptidoglycan type this acid accounted for only 1 or $2 \%$ of the total fatty acids. The cellular fatty acid compositions of $A$. oxydans SAM 1562 and SAM 1563 were similar to those of species with a Lys-Ala-Thr-Ala type of peptidoglycan.

All of the strains had MK-9 $\left(\mathrm{H}_{2}\right)$ as the principal isoprenoid quinone. The $\mathrm{G}+\mathrm{C}$ contents of the DNAs of the test strains ranged from 61.5 to $64.9 \mathrm{~mol} \%$.

DNA-DNA hybridization. The levels of DNA-DNA relatedness found among $A$. oxydans SAM 1562, SAM 1563, SAM 0173, and SAM 0174 and related organisms are shown in Table 3. A. oxydans SAM 1562 and SAM 0173 shared high degrees of DNA complementarity (97 to $100 \%$ ) with $A$. ureafaciens SAM $0299^{\mathrm{T}}$, while $A$. oxydans SAM 1563 and SAM 0174 shared moderate degrees of DNA complementarity ( 47 to $55 \%$ ) with $A$. histidinolovorans SAM $0296^{\mathrm{T}}$, but less than $40 \%$ complementarity with the other test strains.

\section{DISCUSSION}

The genus Arthrobacter is currently defined mainly on the basis of cell morphology and chemotaxonomic characteristics (6), notably peptidoglycan structure $(4,7)$.

The two strains which we received as $A$. oxydans are aerobic, gram positive, motile, and pleomorphic, contain major amounts of dihydrogenated menaquinones with nine isoprene units, have major amounts of iso and anteiso fatty acids (with 12-methyltetradecanoic acid [anteiso $\mathrm{C}_{15}$ ] and 14-methylhexadecanoic acid [anteiso $\mathrm{C}_{17}$ ] predominating), and have DNA base compositions which range from 63.3 to $62.4 \mathrm{~mol} \% \mathrm{G}+\mathrm{C}$. It is clear from these data that $A$. oxydans DSM 419 and DSM 420 belong to the genus Arthrobacter (6).

When we used a new determinative method (see above), we found that both strains of $A$. oxydans had the Ala- $\varepsilon$-Lys peak on chromatograms prepared from their partially hydrolyzed peptidoglycans. Therefore, both strains belong to the group with the Lys-Ala-Thr-Ala peptidoglycan type. $A$. aurescens, A. ilicis, $A$. histidinolovorans, and $A$. ureafaciens also have this peptidoglycan type $(4,7,10)$.

Arthrobacter species have DNAs that are heterogeneous compared with the DNA of the type species of the genus, Arthrobacter globiformis (14). They are rather diverse even when they have the same peptidoglycan type (13). It is clear from DNA hybridization data that $A$. oxydans DSM 419 should be classified as $A$. ureafaciens. In contrast, $A$. oxydans DSM 420 forms the nucleus of a new genomic species although it does exhibit a moderately high similarity value with $A$. histidinolovorans SAM $0296^{\top}$. It can also be distinguished from other Arthrobacter species by a number of physiological properties (Table 1).

Consequently, we propose that $A$. oxydans DSM 420 should be described as a new species, $A$. nicotinovorans.

Arthrobacter nicotinovorans sp. nov. Arthrobacter nicotinovorans (ni.co.ti.no.vo'rans. M. L. n. nicotinum, nicotine; L. part. vorans, devouring, destroying; M. L. adj. nicotinovorans, nicotine devouring). Aerobic, gram positive, not acid fast. Cells exhibit a marked rod-coccus growth cycle in complex media. The rods are motile by means of a few lateral flagella.

Slight growth occurs in the presence of $10 \% \mathrm{NaCl}$. Starch 
TABLE 2. Chemotaxonomic characteristics of $A$. oxydans SAM 1562 and SAM 1563 and related organisms

\begin{tabular}{|c|c|c|c|c|c|c|c|c|c|c|c|c|c|}
\hline \multirow{3}{*}{$\begin{array}{l}\text { Peptidoglycan } \\
\text { type }\end{array}$} & \multirow{3}{*}{ Strain } & \multicolumn{10}{|c|}{ Fatty acid composition (\%) } & \multirow{3}{*}{$\begin{array}{c}\mathrm{G}+\mathrm{C} \\
\text { content } \\
\text { of DNA } \\
(\mathrm{mol} \%)\end{array}$} & \multirow{3}{*}{$\begin{array}{c}\text { Isoprenoic } \\
\text { quinone }\end{array}$} \\
\hline & & \multicolumn{2}{|c|}{ Anteiso acids } & \multicolumn{4}{|c|}{ Iso acids } & \multicolumn{4}{|c|}{ Normal acids } & & \\
\hline & & $\mathrm{C}_{15}$ & $\mathrm{C}_{17}$ & $\mathrm{C}_{14}$ & $C_{15}$ & $\mathrm{C}_{16}$ & $C_{17}$ & $\mathrm{C}_{14}$ & $\mathrm{C}_{15}$ & $\mathrm{C}_{16}$ & $\mathrm{C}_{18}$ & & \\
\hline \multirow[t]{6}{*}{ Lys-Ala-Thr-Ala } & A. aurescens SAM $0298^{\mathrm{Ta}}$ & 66 & 26 & & 2 & 4 & 1 & & & 1 & & 61.9 & 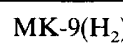 \\
\hline & A. histidinolovorans SAM $0296^{\mathrm{T}}$ & 64 & 22 & 1 & 3 & 5 & 1 & 1 & & 2 & $\operatorname{tr}^{b}$ & 62.6 & MK- $9\left(\mathrm{H}_{2}\right.$ \\
\hline & A. ilicis $\mathrm{SAM} 1581^{\mathrm{T}}$ & 70 & 20 & $\operatorname{tr}$ & 1 & 3 & & 1 & & 1 & & 61.5 & MK-9 $\left(\mathrm{H}_{2}\right.$ \\
\hline & A. oxydans SAM 1562 & 68 & 20 & 2 & 1 & 5 & $\operatorname{tr}$ & 1 & & 2 & 1 & 63.3 & MK-9 $\left(\mathrm{H}_{2}\right.$ \\
\hline & A. oxydans SAM 1563 & 68 & 24 & & 2 & 3 & 1 & & & 2 & & 62.4 & MK-9(H \\
\hline & A. ureafaciens SAM $0299^{\mathrm{T} a}$ & 58 & 28 & 1 & 5 & 6 & 2 & & & 1 & 1 & 63.6 & MK-9 $\left(\mathrm{H}_{2}\right.$ \\
\hline Lys-Thr-Ala & A. citreus SAM $0302^{\mathrm{Ta}}$ & 57 & 8 & 2 & 7 & 7 & 1 & 2 & 1 & 11 & & 64.9 & MK- $9\left(\mathrm{H}_{2}\right.$ \\
\hline \multirow[t]{2}{*}{ Lys-Ser-Thr-Ala } & A. oxydans SAM $0156^{\mathrm{T}}$ & 45 & 17 & 2 & 9 & 11 & 2 & 2 & 1 & 11 & & 63.1 & MK- $9\left(\mathrm{H}_{2}\right.$ \\
\hline & A. polychromogenes SAM $0161^{\mathrm{T}}$ & 44 & 25 & 1 & 3 & 6 & 1 & 1 & 1 & 13 & & 62.9 & MK-9(H $\mathrm{H}_{2}$ \\
\hline
\end{tabular}

${ }^{a}$ Cellular fatty acid data from reference 15 .

${ }^{b} \mathrm{tr}$, trace (less than $1 \%$ ).

is hydrolyzed, and nitrate is not reduced. Nicotine blue is produced from nicotine. Urea is formed from creatinine and uric acid.

Utilizes L-arabinose, D-galactose, D-glucose, meso-inositol, D-ribose, D-xylose, 4-aminobutyrate, L-arginine, L-asparagine, L-histidine, and $p$-hydroxybenzoate, but not L-leucine.

Citric, formic, malonic, uric, and propionic acids are assimilated, but glutaric, adipic, pimelic, and benzoic acids are not.

The cell wall peptidoglycan is of the Lys-Ala-Thr-Ala type, and the principal isoprenoid quinone is $\mathrm{MK}-9\left(\mathrm{H}_{2}\right)$. The fatty acids are mainly straight-chain, anteiso- and isomethyl-branched acids. The major fatty acids are 12-methyltetradecanoic (anteiso $\mathrm{C}_{15}$ ) and 14-methyl-hexadecanoic (anteiso $\mathrm{C}_{17}$ ) acids.

The $\mathrm{G}+\mathrm{C}$ content of the DNA is $62.4 \mathrm{~mol} \%$.

The type strain is strain DSM 420.

\section{ACKNOWLEDGMENTS}

We are grateful to M. Goodfellow, Department of Microbiology, The Medical School, University of Newcastle-upon-Tyne, Newcastle-upon-Tyne, England, for his interest and very helpful discussions. We also thank N. Kawaguchi, Institute for Fundamental Research, Suntory Ltd., for synthesizing the standard dipeptides

TABLE 3. DNA-DNA homology values for $A$. oxydans SAM 1562 and SAM 1563 and related organisms

\begin{tabular}{|c|c|c|c|c|c|}
\hline \multirow[b]{2}{*}{ Fixed DNA from: } & \multicolumn{5}{|c|}{$\begin{array}{l}\text { \% Homology with biotin-labeled } \\
\text { DNA from: }\end{array}$} \\
\hline & $\begin{array}{c}\text { Strain } \\
\text { SAM } \\
1562\end{array}$ & $\begin{array}{c}\text { Strain } \\
\text { SAM } \\
0173\end{array}$ & $\begin{array}{c}\text { Strain } \\
\text { SAM } \\
1563\end{array}$ & $\begin{array}{c}\text { Strain } \\
\text { SAM } \\
0174\end{array}$ & $\begin{array}{c}\text { A. urea- } \\
\text { faciens } \\
\text { SAM } \\
0299^{\mathrm{T}}\end{array}$ \\
\hline Strain SAM 1562 & 100 & 112 & 25 & 21 & 87 \\
\hline Strain SAM 0173 & 88 & 100 & 13 & 31 & 70 \\
\hline Strain SAM 1563 & 27 & 40 & 100 & 104 & 29 \\
\hline Strain SAM 0174 & 24 & 24 & 110 & 100 & 12 \\
\hline A. aurescens SAM $0298^{\mathrm{T}}$ & 41 & 35 & 38 & 39 & 23 \\
\hline A. histidinolovorans SAM $0296^{\mathrm{T}}$ & 25 & 20 & 47 & 55 & 21 \\
\hline A. ilicis SAM $1581^{\mathrm{T}}$ & 36 & 33 & 31 & 34 & 17 \\
\hline A. ureafaciens SAM $0299^{\mathrm{T}}$ & 100 & 97 & 20 & 31 & 100 \\
\hline A. citreus $\mathrm{SAM} 0302^{\mathrm{T}}$ & 13 & 16 & 9 & 10 & 0 \\
\hline A. oxydans SAM $1560^{\mathrm{T}}$ & 9 & 13 & 14 & 20 & 7 \\
\hline
\end{tabular}

and T. Katayama, Institute of Biomedical Research, Suntory Ltd., for technical assistance in the analysis of dipeptides.

\section{REFERENCES}

1. Bodanszky, M., Y. S. Klunsner, and M. A. Ondetti. 1976. Peptide synthesis. John Wiley \& Sons, New York.

2. Eberwein, H., F. A. Gries, and K. Decker. 1961. Über den Abbau des Nicotins durch Bakterienenzyme. II. Isolierung und Charakterisierung eines nicotinabbauenden Bodenbakteriums. Hoppe-Seyler's Z. Physiol. Chem. 323:236-248.

3. Ezaki, T., Y. Hashimoto, and E. Yabuuchi. 1989. Fluorometric deoxyribonucleic acid-deoxyribonucleic acid hybridization in microdilution wells as an alternative to membrane filter hybridization in which radioisotopes are used to determine genetic relatedness among bacterial strains. Int. J. Syst. Bacteriol. 39:224-229.

4. Fiedler, F., K. Schleifer, and O. Kandler. 1973. Amino acid sequence of the threonine-containing mureins of coryneform bacteria. J. Bacteriol. 113:8-17.

5. Hochstein, L. I., and S. C. Rittenberg. 1959. The bacterial oxidation of nicotine. I. Nicotine oxidation by cell-free preparations. J. Biol. Chem. 234:151-155.

6. Keddie, R. M., M. D. Collins, and D. Jones. 1986. Genus Arthrobacter Conn and Dimmick 1947, p. 1288-1301. In P. H. A. Sneath, N. S. Mair, M. S. Sharpe, and J. G. Holt (ed.), Bergey's manual of systematic bacteriology, vol. 2. The Williams \& Wilkins Co., Baltimore.

7. Komagata, K., and K. Suzuki. 1987. Lipid and cell-wall analysis in bacterial systematics, p. 161-207. In R. R. Colwell and R. Grigorova (ed.), Methods in microbiology, vol. 19. Academic Press Ltd., London.

8. Krebs, H. A., and L. V. Eggleston. 1939. Bacterial urea formation (metabolism of Corynebacterium ureafaciens). Enzymologia $7: 310-320$.

9. Owens, J. D., and R. M. Keddie. 1968. A note on the vitamin requirements of some coryneform bacteria from soil and herbage. J. Appl. Bacteriol. 31:344-348.

10. Schleifer, K. H., and O. Kandler. 1972. Peptidoglycan types of bacterial cell walls and their taxonomic implications. Bacteriol. Rev. 36:407-477.

11. Seiler, H., R. Braatz, and G. Ohmayer. 1980. Numerical cluster analysis of the coryneform bacteria from activated sludge. Zentralbl. Bakteriol. Parasitenkol. Infektionskr. Hyg. Abt. 1 Orig. Reihe C 1:357-375.

12. Sguros, P. L. 1955. Microbial transformations of the tobacco alkaloids. I. Cultural and morphological characteristics of a nicotinophile. J. Bacteriol. 69:28-37.

13. Stackebrandt, E., and F. Fiedler. 1979. DNA-DNA homology studies among strains of Arthrobacter and Brevibacterium. Arch. Microbiol. 120:289-295.

14. Suzuki, K., T. Kaneko, and K. Komagata. 1981. Deoxyribonu- 
cleic acid homologies among coryneform bacteria. Int. J. Syst. Bacteriol. 31:131-138.

15. Suzuki, K., and K. Komagata. 1983. Taxonomic significance of cellular fatty acid composition in some coryneform bacteria. Int. J. Syst. Bacteriol. 33:188-200.

16. Tamaoka, J., D.-M. Ha, and K. Komagata. 1987. Reclassification of Pseudomonas acidovorans den Dooren de Jong 1926 and Pseudomonas testosteroni Marcus and Talalay 1956 as Comamonas acidovorans comb. nov. and Comamonas testosteroni comb. nov., with an emended description of the genus Comamonas. Int. J. Syst. Bacteriol. 37:52-59.
17. Tamaoka, J., Y. Katayama-Fujimura, and H. Kuraishi. 1983. Analysis of bacterial menaquinone mixtures by high performance liquid chromatography. J. Appl. Bacteriol. 54:31-36.

18. Tamaoka, J., and K. Komagata. 1984. Determination of DNA base composition by reversed-phase high-performance liquid chromatography. FEMS Microbiol. Lett. 25:125-128.

19. Yamada, K., and K. Komagata. 1972. Taxonomic studies on coryneform bacteria. IV. Morphological, cultural, biochemical, and physiological characteristics. J. Gen. Appl. Microbiol. 18:399-416. 